\title{
The Concept of Ethnic Minorities. International Law and the German-Austrian Response ${ }^{1}$
}

\author{
Samuel Salzborn
}

\begin{abstract}
Following World War I, the League of Nations promoted a liberal system of minority rights conceived on the basis of individual rights and designed to provide human rights protection against discrimination. In reaction to this conception of minorities as deserving democratic protection, an alternate, ethnicallyoriented concept was developed in German-speaking territories, particularly in Germany and Austria, which was based on collective rights and whose goal was ethnically-based legislation (called "Volksgruppenrecht" or "ethnic-group law"). This political concept was gradually developed into a system of international standards. Supporters hoped that ethnically based law would replace international liberal-democratic law. This paper examines how the political paradigm of collective rights was redefined during the 1920 s to produce a conceptual system of legal standards, and how successful efforts were in providing a legal foundation for the sociotheoretical concept of "Volksgruppe" ("ethnic group").
\end{abstract}

Keywords: ethnic minorities; ethnopolitics; international law; history

Conflicts between national minorities and majorities have become a routine part of politics in Europe today. Upon closer examination of the European history of conflicts around ethnic minorities, it becomes clear that - regardless of which national history of conflicts one looks at - it was not until the end of World War I that policies concerning these minorities truly became part of political debate. In the course of the 1920s the foundations were laid for conceptual controversies within minorities policies that have retained even today their potential for complicating and even blocking constructive solutions for conflicts around minorities. The basis for this can be found within a terminological framework that developed in the German-speaking world during the 1920s and 1930s, according to which minorities were not to be treated as equal participants within a democratic political system where they themselves could discuss and negotiate their rights. Instead, German and Austrian debates after World War I developed the notion that national minorities were to be segregated and excluded, denying their possibility of political and social participation within their respective states. This strongly influenced the future handling of conflicts between ethnic majorities and minorities, generally frustrating any attempt at a solution oriented towards negotiation and open-endedness, and, from the very start, encouraging the hardening and long-term cementing of conflict structures. 
The following will trace this debate's development since the 1920s, beginning with an examination of historical changes up until the League of Nations implemented policies protecting national minorities. I will then show how World War I resulted in the first attempts in international law to formulate a comprehensive system of protections for ethnic minorities, and thereby a model for the handling of conflicts with them. My third step will be to look at how the League of Nations' conflict resolution model was answered by German and Austrian policy developments that would exacerbate conflicts with minorities by encouraging fragmentation along social and ethnic fault lines. During the German Weimar Republic and the Austrian First Republic, these ideas still remained on the level of conceptual proposals; it was the National Socialist regime that then radicalized and implemented them, thereby politically and militarily destroying the first international legal system for the constructive handling of minorities conflicts. Finally, the summary will briefly analyze possible implications for the handling of minorities conflicts.

Here, the concept of minorities refers exclusively to ethnic minorities. However, the concrete definition of this is debatable - and this debate also forms part of the conflict surrounding ethnic minorities as described below. A clear, positive definition of the term "ethnic minority" would be a group that claims an ethnic identity of its own, or one that is assigned such by an outside party. This ethnic identity, whether coming from within or without, is significant not only within an individual's makeup, but also in the political arena. Ethnicity thereby becomes a decisive element in the relations between a state and those minority groups settled within its borders.

This paper seeks to sketch out the emergence of nationality law in German-speaking Europe, focusing particularly on the developments of the 1920s. With the end of World War I and the installation of a new European order emerging from the Paris Peace Conference of 1919, the German-speaking territories saw developments in international law oriented towards a particular conception of minorities: these sought to abrogate laws protecting individuals from discrimination and replace them with a system of collective, ethnically based legal privileges.

The international legal provisions outlined by the League of Nations had been conceived in terms of individual rights, especially in terms of antidiscrimination protection; in the 1920s, German and Austrian members of the völkisch ("folkish" or "ethnicist") movement instigated a fundamental shift in legal theory by proposing nationality laws or Volksgruppenrecht ("ethnic-group law") ${ }^{2}$ built upon collective and ethnicizing special legislation. Borrowing from the theory of the "eigenständiges Volk" ("discrete and independent ethno-nation") formulated by Max Hildebert Boehm, a legal system was to be created in explicit opposition to the liberal minorities policies of the League of Nations. The theoretical repudiation of these policies extended to the terminological level, so that the debate was no longer about protecting minorities, but about nationalistic policies. This paper will show to what extent a political paradigm was reshaped in the 1920s into a conceptual system of legal standards, and how successful efforts were to legally underpin the sociotheoretical construct of the ethnic group. 


\section{On the origins of international protection for national minorities}

Although the criterion of ethnicity has been particularly significant in the recent history of minorities protections, it did not play a role in their genesis (cf. Pircher 1979, 54; Pritchard 2001, 51). Protections for minorities were at first not ethnically based, since only with the development of the modern nation-state did ethnicity become an important distinguishing criterion between the particular constituent groups of a state or in crossborder negotiations; nationalist issues first appeared in the 18th and 19th centuries, and conflicts that once had religious difference as a starting point now became framed in nationalist or ethnicizing language. During the close of the late Middle Ages and the beginning of the Modern Age, these protection mechanisms (which were unilateral and without concrete international enforcement) tried to address the Catholic and Protestant minority populations that had developed as a consequence of the Protestant Reformation, as territorial transfers of the time, combined with guaranteed freedom of emigration and allegiance, led to demographic shifts between these denominations in various territories. Therefore, the issue of religious tolerance was already appearing in international law back then. Protections for these confessional minorities thus represent early forerunners for later laws protecting ethnic minorities, as will be expanded upon.

After the Peace of Nuremberg - generally regarded as the earliest instrument of protection for religious minorities - and the Peace of Augsburg, the Peace of Westphalia is of particular significance, because it outlined the first international regulations on minority protections, if only for certain Christian confessions. The Peace of Nuremberg was the first constitutional document to establish a "general peace" for Protestants, while the Peace of Augsburg at last offered recognition to the Lutherans (cf. Heckel 2007, 13). This established a general public peace in which Protestant and Catholic states of the Holy Roman Empire extended recognition to one another. Through this peace agreement, each imperial state was given freedom of religion, meaning each ruler had the right to choose a church for himself and his Christian subjects ('cuius regio, eius religio'); furthermore, inhabitant subjects professing an opposing denomination, who might have objected to that of the local ruler, were accorded the right of free, unchallenged emigration (cf. Heckel 2001; Klueting 2007). However, these rights were given only to free Christians of certain specified denominations; they did not apply to serfs, Jews, or other religious minorities.

The Peace of Westphalia thus granted equal standing to Catholic and certain Protestant confessions, while specifically adding Calvinism to the legal framework defined by the Peace of Augsburg; each group was given corresponding rights even when living under rulers of opposing denominations, and was also guaranteed the right to emigration and the protection of assets. Subsequently, European bilateral treaties would increasingly include standard provisions for the freedom of religion and the protection of religious minorities.

The protection of religious minorities, still today a principle of international law, is comparable to the modern democratic concept of protections for national and ethnic minorities, in that members of minority groups are understood as individuals and not as collectives, thus conceptualizing such protections as rights attached to the individual and not in terms of collective obligations. The focus was on the individual as a legal entity who was guaranteed the free exercise of belief (cf. Kugelmann 2001, 255). This approach can be characterized as an antidiscriminatory, referring here to potential discrimination on religious grounds; its motivation is similar to modern conceptions of antidiscriminatory protections on various other grounds, including ethnic ones. In retrospect, this parallel 
can be seen in later regulations for the legal protection of minorities, in which religious grounds are always listed among others (cf. Lanarès 1964).

Therefore, the protection of religious minorities before the emergence of modern society can certainly be seen as a model for, or even as a forerunner of, later minority protections conceived as human rights protections that underpin efforts to protect the private individual against discrimination.

However, a discontinuous momentum in the development of international legal protections for minorities can be seen in the ethnicizing tendencies of later conceptualizations of ethnic-group law, the presumption of human biological and cultural differences needing protection and enhancement, and the segregation of people according to ethnic criteria. In fact, the goal of modern legislation on ethnic groups stands in direct opposition to the basic philosophy behind legislation protecting the individual from discrimination through enforcement of the principle of tolerance, as exemplified by religious minority protections; instead, ethnic-group legislation strives for the collective differentiation, classification and separation of people (cf. Salzborn 2005b, 81).

One of the first attempts to protect national minorities under international law can be seen in the Final Act ratified on 9th June 1815 at the Congress of Vienna: According to Art. 1, Par. 2, Polish inhabitants (who had variously become subjects of Russia, Prussia, or Austria, and thus minorities within these larger states, despite forming the majorities within various regions) were assured a national representation within a confederation of multiple nationalities in accordance with the legal framework of their respective territorial rulers (cf. Pan 1999, 72). Since the signatory states of this treaty were also the guarantor powers behind this agreement, it can be stated that Art. 1, Par. 2 broadly addresses the national rights of a people, that is, the bona fide protection of a national minority under international law - albeit with only limited application (cf. Duparc 1922, 114). Despite the existence of this early example of minorities protections in international law, many legal historians identify only later protections emerging at the end of World War I as being the first, broadly valid ones (cf. Jellinek 1898; Veiter 1968, 227). The scholar of international law Rudolf Laun (Laun 1923, 256) even goes so far as to say that it was only World War I that "facilitated the emergence of international nationalities legislation" at all.

However, in evaluating the history of minorities' rights, it could be argued that these aspects of international law were not as important as other developments occurring in the domestic field at the time. It was not just that some states had enshrined protective measures for minorities: more importantly, these very measures had introduced a conceptual differentiation that would become elementary to the discussion of minorities and ethnic groups, in which the idea of "minority", originally understood in purely numerical terms, became terminologically equated with "nationality" and/or "Volksstamm" ("tribe") (cf. Kann 1964, 40). Up until then, the concept of the national and/or ethnic minority had been relatively unknown in the legal-positivist sense. The Austro-Hungarian Empire was the first state to enshrine this type of minorities legislation, but did not provide for linguistic or national minorities in the sense of an ethnicized differentiation between majority and minority ethnic groups; instead, the Empire recognized only the majority groups of individual territories. Accordingly it recognised those known as Austrian Germans in the Austrian territory (the Cisleithanian half of the Empire) and Magyars in the Hungarian section (the Transleithanian half) (cf. Veiter 1984, 19). The dual monarchy was understood as a multinational state, irrespective of whether one of these groups was to be interpreted as foundational to the state. Since Austria-Hungary was not a nation-state in the sense of a republican civil society, it did not classify inhabitants according to minority- 
majority lines, but rather nationality and tribe. ${ }^{3}$ Terminologically speaking, the concept "tribe" was to anticipate the greater autonomy of each of the referent groups: while a minority always depends by definition on a majority, without which it would not actually exist as such, a nationality or tribe is an autonomous entity on the emancipatory path towards becoming a Volk and/or nation, united by collective characteristics with positive connotations. The term Volksstamm is applied to an "ethnic group with an ancestral area of settlement ('Heimat' or 'homeland'), a consciousness of community, and a certain degree of social and organizational articulation." (Veiter 1970,1) Therefore, it was first with the "ethnicization of politics in old Austria" (Stourzh 1999, 35) during the midnineteenth century that the fields of law and politics saw the emergence - as a functional agent under the rubric of nationality rights - of the ethnic group:

"In the Austrian half of the Empire it became legal and factual, while in the Hungarian half it became legal theory but not actually constitutional; it became the basis of characterizing the various ethnic communities according to truly Volksgruppe-oriented criteria; in other words, it gave them recognition as articulated, socially real, ethno-national communities. These were to be maintained and protected as such, and they were to be supported as communities." (Veiter 1970,1) (translated by the author)

Core elements of the rights guaranteed to the nationalities were set out in Art. 19 of the Austro-Hungarian Constitution of 1867:

"1. All the races of the state shall have equal rights, and each race shall have the inviolable right of maintaining and cultivating its nationality and language.

2. The state recognizes the equality of the various languages in the schools, public offices, and in public life.

3. In the countries populated by several races, the institutions of public instruction shall be so organized that each race may receive the necessary instruction in its own language, without being obliged to learn a second language." (doc. in Dodd 1909; the term "Volksstamm" is here translated as "race", but "tribe" would be equally valid.)

Until the end of World War I, Austria-Hungary remained the only state in Europe defining the constitutionally protected rights of nationalities (if only the two dominant ones) as a legal obligation that was actionable before the Constitutional Court.

\section{Conceptualizations of minorities protections in international law after World War I}

After World War I, the ratification of the Paris peace treaties reconfigured the states of the European continent, drawing new borders and establishing new countries (e.g., Czechoslovakia). A major consequence of this new order was the emergence of certain new national minorities, often living in - but not limited to - the newly created border regions. Previously inhabitants of another state, they in some cases found themselves marooned by the radically modified political and social frameworks. The Paris peace treaties in-

3 Franz Pan (Pan 1999, 73) points out that it was only with the settlement between Austria and Hungary and the granting of equal rights to both peoples in 1867 that one can even speak "of a minorities protection in real terms". In contrast, Otto Kimminich (Kimminich 1980, 43) states that the "nationalities and Volkgruppen problem" of old Austria after 1867 "as a whole", cannot be considered "in the perspective of minorities protections", because a nation-state did not exist. 
cluded provisions for the protection of minorities in the relevant states, with the goal of preventing new conflicts and threats to the peace; nonetheless, new conflicts did emerge, ranging from divided loyalties and irredentist movements to governmental and social discrimination (cf. Pritchard, 2001; Scheuermann 2000).

The minorities protections emerging after World War I largely avoided a language that would reinforce a sense of ethnic identity, as would happen if ethnic groups were recognized as collective entities; such identity-building had played a profound role in the development of Austro-Hungarian legislation concerning nationalities. During the League of Nations era, international legal provisions for the protection of minorities were based upon relevant treaties ratified by the Allies (and their associates) with the states of eastern and southeastern Europe; these were designed with the general goal of conflict prevention (cf. Azcárate 1945; Pearson 1983). Formally, this system of protections during the League of Nations era utilized that classic instrument of international law, namely the multilateral treaty, which required implementation within the domestic legislation of each signatory state; this system foresaw implementation through a guarantee from the international community, as organizationally represented by the League of Nations (cf. Kimminich 1980, 49).

These treaties led to the development of a broader system of democratic protections for minorities; this was praised not only for guaranteeing protections to a previously unknown degree, but especially for emphasizing republican aspects over ethnic ones, thus reflecting a generally antidiscriminatory philosophy. Regarding this pluralistic approach, I align myself here specifically with the analysis of Franz L. Neumann (Neumann 1966, 161), who states that the philosophy of minorities protection reflects "the best heritage of liberalism", in specific reference to the relevant treaties of the League of Nations era.

In his work on the minorities policies of the League of Nations, Martin Scheuermann (Scheuermann 2000,29) provides an articulate summary of the foundations of relevant protections under international law:

"The [...] rights were generally no different from those commonly accepted obligations that a state under the rule of law would normally have towards each and every one of its citizens. The notion of 'positive discrimination', which is a key idea in modern minorities protections, was still completely unknown as such, although the general spirit of this idea was already being called for by a few theorists on minorities policy. Minorities protections guaranteed only the rights of individual persons, and granted no entitlements to groups. The signatory states were very conscious of their own internal as well as external sovereignty, and wanted to avoid at all costs the creation of such "states within the state' that result from collective group rights." (translated by the author)

In fact, this fear was not unfounded. Looking back upon developments during the League of Nations period, it becomes apparent that the practical failures of minorities policies were due not only to the inadequacies of the Minorities Section of the League of Nations (cf. Gütermann 1979; Palleit 2008; Reydellet 1937, 59; Scheuermann 2000, 30), but also to the politics of irredentism and Volkstum ("folkish cultural identity") among those minorities living in border zones, especially in regions adjoining the German Empire. It was these politics of Volkstum and irredentism, frequently stimulated by outside influences, that were to provoke the emergence of a whole series of conflicts in the first place (cf. Bamberger-Stemmann 2000, 35).

Even though absolutely no domestic obligations towards minorities were imposed upon the German Empire (cf. Göthel 2002), many Germans still considered their state (along with Austria-Hungary) to be the main loser of the First World War. Military defeat and the resultant Treaty of Versailles led to numerous territorial losses for Germany: 
France took back Alsace-Lorraine, Belgium received the district of Eupen-Malmedy, most of North Schleswig went to Denmark, Danzig became a Free City under the protection the League of Nations, the Memel Territory came under Allied administration, and Poland reclaimed the Province of Posen, most of West Prussia, and parts of Upper Silesia. Additionally, Germany had to give up all of its colonies.

As a result of the Treaty of Versailles, all ethnic Germans inhabiting these regions became "foreigners", and, according to the interpretation of Volkstum, they were now members of Grenz- und Auslanddeutschtum ("Germanhood of the borders and abroad"). Despite living outside of the German state, these people were considered part of the German nation, in accordance with ethnicist theory: "The concept of Auslanddeutschtum is independent of national citizenship; the only valid criterion is Volksgemeinschaft ("folk community')" (Grothe 1921, 38). After the demands of World War I, Germany was struggling to find a commensurate place in the international order, wanting to secure for itself new colonies and markets by conquest. The loss of colonies and borderlands was perceived to be an especially unjust clause of the so-called "disgraceful peace of Versailles"; this treaty was abhorred by all political parties in Germany - a phenomenon aptly described by Hans Mommsen (Mommsen 1989, 101) as an "inner rejection of the peace". All other acts were seen as further humiliations, becoming intimately connected to the question of Deutschtum abroad, and forming the basis of a common "ethno-national identification" (Münz/Ohliger 2001, 373).

\section{The ethnicist response to minorities conflicts: Volksgruppenrecht}

The irredentist and German nationalist movement in Germany and Austria found support through the almost universal domestic criticism of the Treaty of Versailles. Among other developments (such as the explicitly imperialist and expansionist ideas of the "PanGermans"), they began to emerge within the movement's intellectual circles an ethnically oriented stream, turning against the liberal-democratic provisions of the minorities protection treaties while attempting to formulate an explicitly ethnicist counter-ideology (cf. Boehm 1959, 9). The core of this project was the acceptance of the concept "eigenständiges Volk", as formulated by Max Hildebert Boehm (Boehm 1932), which formed the most important theoretical foundation for developing policies concerning European folk groups during the Weimar period.

Boehm, the "prophet of ethnopolitics" (Haar 2000, 27), and one of the most important theorists of Volkstum in the Weimar Republic and National Socialism, attempted to systematically contrast the idea of "Volk" against all other political and social categories (cf. Boehm 1932, 17, 265). Central for him was dissociating the idea of "Volk" from the categories of nation/state, disconnecting it from the western conception of nation that also happened to be the basis of minorities protection treaties. The project was to emphasize the independence of the German Volk and help it to gain supremacy in Europe. This "German sense of 'European' mission" was reinforced, as aptly explicated by Ulrich Prehn (Prehn 2001, 57), by constant references to the Volkstumkampf ("struggle of ethnic identities") and the protection of the homeland on the German frontiers, as a "parallel motif to the alleged 'westernization' of central and eastern Europe", for which "particularly France, England, and Wilson's League of Nations and minorities policies" were to be made responsible. Boehm's works on Volk theory and ethnopolitics delivered "'magic formulas' for the foundation of a German collective identity, which, like the emotionally 
loaded project of the yet-to-be-realized Volksgemeinschaft, were designed to destroy the international order of nations and 'folk groups' that emerged in Europe after World War I." (Prehn 2001, 58)

The theory of the sovereignty of the Volk may have focused on the German Volk, but it certainly did not deny the independence of other nations or folk groups; on the contrary, it generally assumed the then ubiquitous formula of a "Volk unter Völkern" or a "people among peoples" (cf. Loesch 1925), leading from the theory of disputed borders, as formulated by Boehm (Boehm 1923, 310), to "Europa Irredenta" (Boehm's term for a Europe containing territories needing to be "reclaimed"). In the struggle against the League of Nations and towards the "overthrow of French domination of the Continent", the "release of Volkstümer from centuries of state stranglehold" through the dismantlement of western (i.e. democratic and republican) "state omnipotence" should lead to the growth of a "völkischer Freiheitsbereich" ("ethnic zone of freedom") (cf. Boehm 1923, 316, 320):

"Healthy political consolidations in the modern state order will prevail in the long run; however, the abolishment of the most egregious disunifications and dismemberments of suppressed Völker is a prerequisite for the political as well as the economic reconstruction of Europe. In this regard, an attempt must be made to identify the broader geopolitical territorial units of the Continent and give them shape." (Boehm 1923, 314) (translated by the author)

The basis for this was to be the "recognition of each Volk as a Volkspersönlichkeit ('the Volk as a legal person') and thereby as the natural foundation of the new Europe" (cf. Loesch 1926, 50). In this theory, the folk groups functioned as "natural federations or corporations" within each individual state, which for its part was to confer "nationalcorporational rights" so that the various folk groups would be able to determine "their own lives autonomously" within the arena of "national-cultural life" (cf. Raschhofer 1980, 67). In order to appropriately sanction this model on a supranational level, liberaldemocratic citizenship would be countered with an ethnically based Volksbürgerschaft ("membership in an ethno-national group"), which would be made valid across borders (cf. ibid.).

In this way, folk-group theorists positioned themselves in direct opposition to the "Paris Minorities Protection Treaties", as these were called by the Austrian theorist on international law Hermann Raschhofer, who was one of the most prominent proponents of folk-group theory. These treaties were criticized because "within minorities law, nationalities are forced to live with the legal status of being seen as atomized national individuals", without receiving recognition as "organic legal persons" and without existence as "valid legal persons possessing rights" (Raschhofer 1931, 76, 78):

"Nationality is [...] not some characteristic that accidentally appears in every and any citizen per se, bringing people together, as it were, as just an after-thought; it is not like strangers being thrown together as members of an association representing some common interest; it is not just the sum of parts, but rather the totality." (Raschhofer 1931, 77) (translated by the author)

According to this understanding, a nation only existed when "its members organically and communally, and especially historically and culturally, perform as a positively qualifiable folk group" (ibid.) Consequently, nationalities' rights only exist when "a national differentiation of persons also results in a legal differentiation", leading towards the goal of "establishing empires and corporations each possessing legal personhood in their own right." (ibid., 154)

In opposition to liberal positions on the minorities question, ethnically oriented proponents were striving for a "new legal construction" (Bodensieck 1958, 507) within interna- 
tional law, while constantly emphasizing the (ethnic) independence of minorities by using the terms "nationality" and "folk group". In accordance with assumptions of the folkgroup theory of the 1920s, minorities and folk groups were to be considered as "intercountry co-nationals". Despite having already established a certain conventionalized validity, they had, "as yet, hardly come to any clear, systematic and definitive expressions" in terms of international law (cf. Boehm 1927, 147), ${ }^{4}$ which meant that this concept had not yet developed any internationally legal relevance. The "co-nationals" create for themselves "at first their own basic legal system founded upon natural law, which, through collisions with the norms of the state-mandated positive system, [...] becomes embroiled in severe conflicts: a legal system which can be theoretically explicated and governmentally enforced within the core territory of the nation-state." (cf. Boehm 1938, 153) The "metapolitical essence" of ethnically oriented autonomy provisions would thereby be based on its "own laws, which should be completely separated from external influences and even from recognition as positive law", as stated by Boehm (Boehm 1927, 141), in contrast to the international laws then in force. The concept of autonomy represented "just a historical precursor to state sovereignty" - and thus the essential legitimation for separatism and separation (cf. ibid., 136). Carl Georg Bruns (Bruns 1929, 17) summarized this contradiction between law and politics thus:

"The idea that the Volksgemeinschaft, founded on the basis of legal personhood and independent of borders, should stand next to the state on a legally equal basis, is a complete departure from the essence of the minorities treaty laws already in force. This idea is so influential in the struggle to redefine the national idea, and it could become so decisive in the realignment of Europe, that when compared with the laws of the treaties [...] there is nothing left in common." (translated by the author)

While each ethnically defined minority had become the subject of the ethnically rationalized struggle against the liberal-democratic minorities system of the League of Nations, it was the concept of "national (and cultural) autonomy" that had become the object of desire among folk-group theorists in the interwar period (cf. Veiter 1938). However, the legal framework for the concept of national autonomy had not been established by any norm of international law - which was itself shaped by the liberal minorities laws of the League of Nations - but instead, was exclusively based on the domestic legal systems of individual countries (cf. Dörge 1931). There was "no provision in international law through which a folk group was directly awarded collective rights (of personhood) as an entitlement under such law", as stated in 1938 by the Vorarlberg scholar on international law Theodor Veiter (Veiter 1938, 73).

The concept of ethnically based autonomy was thus understood as being a stand-alone legal entitlement within the domestic context, while at the same time being lauded as "neither arbitrary nor time-limited" (Gerber 1926, 251) due to its standing under natural law; therefore, it should be valid "for all time" ("zeitewig"), according Max Hildebert Boehm's (Boehm 1932, 222) formulation in reference to the concept of Volk. The concept of national autonomy thus represented the theoretical peak of folk-group theory; in fact, it was regarded as the "provision of folk-group law most in accordance with the essence of Volkstum", because it actualized "the recognition of the legal personhood of the

4 Boehm (Boehm 1935, 79) spoke later of "gesamtvölkische Konnationale”, with gesamt meaning "as an entirety", revealing with this choice of words even more clearly the political implications. 
Volksgruppe", as written by Theodor Veiter (Veiter 1938, 81) which was probably the most important work of the 1920s and 30s on the subject of folk-group law.

\section{The ethnicist attack on international minorities laws}

Regarding the significance of the ethnicist contribution to anti-democratic thought in the Weimar Republic, Kurt Sontheimer (Sontheimer 1994, 247) wrote that, in accordance with the notion of the "independence of the Volkstum and the belonging of all Germans to one Volk", the treaty-related

"ethnicist minority problems, and in fact the founding of new nations at all, were put in a critical light. From the 'Europa Irredenta' left behind by Versailles, a new order in accordance with ethnicist principles was proposed, i.e. state borders should coincide with ethnic borders. This, and not just the recreation of the old borders, was the goal enjoined by ethnicist ideology upon the extraordinarily active efforts of nationalist groups representing Germanhood abroad." (translated by the author)

Therefore, within the ethnically oriented political stream of the Weimar Republic, the focus was shifted away from the bourgeois-democratic subject of Nation and towards the ethnic subject of Volk. Parallel to the displacement of the word "nation" in popular and scholarly usage, the term "nationalities" (as well as "minorities") started being supplemented with the term Volksgruppe ("folk group"); this, as observed by Martin Broszat (Broszat 1958, 58), signalled an "internal turning away" from the "western, liberaldemocratic concept of 'nation' as shaped by the French Revolution". In the early 1920s, critics of the term "minorities" took the term "folk group" and "re-made" (Boehm 1959, 26) or politically "launching" it (Kloss 1969, 68), and thus for the first time introducing it into the social linguistic context as a highly effective and deeply meaningful term. Without a doubt, Austro-Hungarian laws on nationality functioned here as a partially adaptable inspiration for folk-group theorists during the interwar period; however, by drawing on the collective momentum of the concept of the "eigenständiges Volk", the "terminological shift" (Raschhofer 1964, 83) came to further assert itself within the linguistic context of minorities politics, so that the anti-Enlightenment ethnicist agenda manifested its antinational (and anti-state) sentiments on the level of language and symbol too. While the term "nationality" refers to the core term "nation" (which also exists in republican thought), the term "folk group" points towards the term "Volk" (in the ethnic sense) as the basic unit. The League of Nations' democratic minorities policies were associated with the territorial capitulations of the German Empire and the dissolution of the Austro-Hungarian double monarchy after the end of the First World War. Folk-group theory was a conceptual response that was very effective in establishing itself on a linguistic level as a selfcontained blueprint for a normative system of international law.

Therefore, the folk-group concept was formulated as a sociotheoretical paradigm in fundamental opposition to the European minorities laws of the League of Nations era; this concept oriented itself against the liberal-democratic ramifications associated with those laws, and thus found great resonance in the ethnicist movement of the time. Since

5 On the conceptual dimension of the here underlying social construction of boundaries, see Pinwinkler 2003, 31.

6 Cf. in depth on the term "Volk" Hoffmann 1991. 
the folk-group theory had no anchors in international law, it was conceived as a natural law system, although with the presumption of the "Volk" and folk group as sociological facts (as opposed to specific, ideological interpretations of social reality) that needed to be transferred into normative legal systems.

At the centre of the folk-group concept of the 1920s stood (on the one hand) the orientation towards national-corporate rights for minorities that were considered essentially different from the majority, and (on the other hand) the polarization between state citizenship and Volksbürgerschaft. This double challenge to the European system of civil nation-states during the interwar period culminated in the failure of the attempt to transfer the folk-group concept into European minorities legislation to the international level; this situation only changed with the political attempt by the National Socialists to rearrange Europe according to ethnicist premises.

In diametric opposition to the concept of minorities protections under international law, National Socialism pursued the goal of developing a constitutional system (in accordance with folk-group theory) that was oriented towards establishing an international legal system denying the sovereignty of the nation-state; this new international order would be founded on an ethnically oriented, anti-Enlightenment, natural law (cf. Neumann 1966, 150). According to National Socialism, the necessary basis for a functioning international law was not the formula of rationalism plus sovereignty, but rather a "shared basic mindset in politics and ideological world view" emerging from the "general acceptance of the ethnic principle" (Klauss 1937, 107). The starting point was not a "liberaldemocratic-statist" but rather an "ethnically defined Europe", and since Germany was supposedly the only European state in which the beginnings of this kind of legal conception were constitutionally anchored, it was expected to take up the missionary task of exporting this legal philosophy to all of Europe (cf. ibid.).

Liberal-democratic minorities laws were "in tenor and form, essentially a liberaldemocratic, individualistic legal institution", and were therefore also rejected by the Nazi state, because these laws boiled down to a quantitative definition of an official state Volk, while, for the National Socialists, only a "qualitative definition" could be decisive (cf. ibid., 51). It was about the "conservation and promotion" of "ethnic elements" (Ziegert 1937,5 ), and of the folk group as a "Blutsgemeinschaft" ("blood community") with "ethnic characteristics", ostensibly defined by "objective attributes" ("derivation") and not by individual self-identification (Klauss 1937, 52).

Only those minorities having the citizenship of their local state, but possessing membership in a supposedly different Volk, could be considered folk groups; in contrast, "members of foreign states, who lack any feeling for the folk group's imperative", were subject to "Fremdenrecht" ("foreigner laws"), "when they live in Germany" (cf. Ziegert 1937, 22). Furthermore, the various folk groups were divided into two "classes", called "artverwandte" and "artfremde" (typologically "related" and "unrelated") (cf. Klauss 1937, 54). The "related" included all folk groups that "exhibited a racial make-up similar to the German Volk, meaning all Germanic folk groups, and broadly speaking all 'Aryan' ones", while the "unrelated" (being definable only in contrast) included those folk groups that were "neither blood relations nor members of the European community", meaning "Jews and Gypsies in particular" (ibid., 54). Since the "unrelated" were "not members, but rather Fremdkörper ('foreign bodies') in the community of European peoples", they were not subject to folk-group law but rather to "a special Artfremdenrecht ('law system for the unrelated")" (ibid., 55). The "absolute estrangement of the racially different (eg. the Jews and the Gypsies)" was therefore seen as the "necessary consequence" of this Volk and folk-group conception (Walz 1939, 150). 
This meant that while National Socialism was demanding the establishment of a "racist system of international law" (Diner 1989, 23) and rights for (ethnically German) folk groups on a foreign policy level, it was also categorically denying these same rights on a domestic level to other people who would also have been considered members of folk groups (according to Nazi criteria), had they been living in other countries. The foundation for this was the legal and political differentiation placing Staatsangehöriger (citizens living under the "protection of the German Empire") and Staats-/Reichsbürger ("Staatsangehöriger with German or 'related' blood") on the one side, and the concomitant construction of the "unrelated" on the other, thus forming the basis for racially justified antisemitic special legislation (cf. Benz 1988; Walk 1996):

"No other state, before or since, had presumed to dictate who could inhabit the Earth and who should disappear from the land, who could sire and bear children and who not, who could live and who must die." (Schwarz 1996, 28) (translated by the author)

Therefore, National Socialism's folk-group policies were dominated by three encompassing principles. First, striving for the recognition of German minorities abroad as corporately organized folk groups with corresponding collective privileges, culminating in separatist provisions for autonomy. This stood immediately next to the goal of relocating German minorities to the German Empire or to annexed territories, whose current inhabitants were first either expelled or more often murdered in accordance with racist and antisemitic motives. These two aspects were subordinate to the central goal of Nazi Volkstum policies and Nazi ideology overall: the mass destruction of European Jews.

Instead of minorities protections being under international aegis, guarantor authority for each folk group was shifted to the originating motherland as the "political guardian of the minorities", which meant, as Franz L. Neumann (Neumann 1966, 163) pointed out, "not only the rejection of rational international relations", but "also the end of internal unity in every state having sizeable minorities":

"This technique characterizes the whole conceptual and intellectual framework of National Socialism. In their hands, the 'concrete personality' of the folk group really means differentiation among the groups so to play one off against the other. The conqueror imposes a hierarchy of races. The folk-group idea is nothing but a device to hold some groups down while inviting others to share in the spoils of the conquest. [...] Descent takes precedence over citizenship. Racial Germans throughout the world remain Germans, members of the folk group, subject to its law. [...] Recognition of the minority as a public corporation, as the Germans understand it and have applied it in Czechoslovakia, Hungary, and Romania, thus creates a state within a state and exempts the German group from the sovereignty of the state." (Neumann 1966, 163)

Liberal-democratic efforts to avoid "states within the state", embodied by minorities protections founded on the rights of the individual, were now being inverted by folkgroup policies and extended to include the ethnicist intervention policies of the National Socialists, informing their political agendas and dictating their actions. Nonetheless, the attempt to transfer the folk-group concept into broader international law was a failure. The Nazi legal conception was still only voluntas and no longer ratio, thereby eclipsing the universalist premise with a decisionistic legitimation of brute power and force - the liberal minorities laws of the League of Nations period may have thus been politically destroyed, but they were not to be replaced by an ethnicist world order (cf. Claude 1955). 


\section{Summary}

From a political science perspective, an analysis of developments in the handling of minorities conflicts after World War I reveals the following:

Beyond the political, societal and social conflicts between national minority(-ies) and majority(-ies), an ever-present and important role is also played by the increasingly fine distinctions in terminology as well as the insinuation of interpretative overtones within the constellation of conflicts - therefore, in the analysis of minorities conflicts, it is never irrelevant as to whether one speaks of a minority, a nationality, or a folk group/Volksgruppe, because each of these terms implies a specific understanding of how the conflict should be handled, and these understandings are in many respects mutually exclusive. Here, the key categories according to which a solution to minorities conflicts can and must be discussed are defined first by the question as to whether a minorities policy is oriented towards the individual and his/her protection from discrimination, or the collective and its (dis-)entitlement through discriminatory laws (cf. Brown 2000; May 2008; Schmid 2001). This is connected to a more general understanding of minorities and nations: are these to be understood in the sense of demos, or in the sense of ethnos? The first option emphasizes the democratic mutability of identities as assigned by the self and by others, allowing for a heterogeneous conception of identity, while the second option tries to insist on an immutable set of identities, using this concept of ethnic identity to permanently exclude and isolate other people.

The conception of nations and minorities based on the demos model is built upon the principle that a population constitutes a nation-state arising from a conception of sovereignty that posits the existence of political equality (regardless of criteria such as language, origin, culture and social status) and exercises state sovereignty accordingly, which means ruling over its territory using defined representative mechanisms. Within democratic theory, this model was typologically described by Ernst Fraenkel as an "autonomously legitimate, heterogeneously structured, pluralistically organized constitutional state" (Fraenkel 1991, 326).

According to the social conception founded on the demos model, membership in a nation or minority is not simply a result of citizenship papers; rather, one is a citizen in the full sense of the French citoyen, freely choosing to legally identify oneself as a member of the nation and to share responsibility for this constituent state.

This can be contrasted against the attitudes, conceptions, and political movements emerging from the theory of the ethnos, taking as a basis the ethnic interpretation of the nation and/or the minority as a Volk or Volksgruppe. Here, one attempts to build an identity between the members of an ethnic group, the territory they populate, and their formal membership within respective regional and/or state organizations. In this conception, the imperative of ethnicity becomes the central focus, forming above all the constitutional foundation of the Volk, which is understood as a comprehensive ethnic collective. This ethnic identity, built upon linguistic, cultural and historical traditions that are partly factual, partly fictive, is used to legitimize the struggle for ethnic independence, contributing to broader demands for cultural and/or state autonomy within the framework of a collective interpretation of minorities rights.

The third basic dimension emerging from a political-science analysis of the historical materials is the question of whether minorities conflicts must or should be solved through political or legal means. Here, historical experience offers valuable clues indicating that the answers to this question are never absolute, but only relative, because the potential for shaping political solutions is also dependent on how well the existing laws already protect 
minorities from discrimination. This in turn points to the importance of the national context of minorities conflicts, because the handling of minorities conflicts must still be ultimately worked out in practical terms within a nation-state's societal spaces: During the League of Nations era, it was seen that legal protections are only effective when they were locally incorporated into a nation's legal code and accepted by its political culture. Therefore, an analysis of the legal treatment of minorities conflicts after World War I shows that the legal dimensions of minorities policies must always be discussed in close relation to the political culture.

This brings up the question of how much a political culture is characterized by ethnic fragmentation and how much by democratic participation. Here, according to Anton Pelinka (Pelinka 2009) and Arend Lijphart (Lijphart 1977; 1999), fragmentation within a society means the existence of subsocieties that assign themselves a specific identity that inform political loyalties and a particular political attitude - either for or against the state in which they live. The more a political culture and thereby its political system tolerates or even encourages ethnic fragmentation, the stronger the centrifugal tendencies become within a society, which can lead to an erosion of the political order, and ultimately to its destruction due to ethnopolitical forces.

\section{Bibliography}

Azcárate, P. de (1945) League of Nations and National Minorities. Washington D.C.: Carnegie Endowment for International Peace.

Bamberger-Stemmann, S. (2000) Der Europäische Nationalitätenkongreß 1925 bis 1938. Nationale Minderheiten zwischen Lobbyistentum und Großmachtinteressen. Marburg: Herder-Institut.

Benz, W. (Hg.) (1988) Die Juden in Deutschland 1933-1945. Leben unter nationalsozialistischer Herrschaft. München: Beck.

Bodensiek, H. (1958) Volksgruppenrecht und nationalsozialistische Außenpolitik nach dem Münchener Abkommen 1938. In: Zeitschrift für Ostforschung, Vol. 7: 502-518.

Boehm, M. H. (1923) Europa Irredenta. Eine Einführung in das Nationalitätenproblem der Gegenwart. Berlin: Hobbing.

Boehm, M. H. (1927) Die Nationalitätenfrage. In: Salomon, G. (Hg.) Jahrbuch für Soziologie, Erster Ergänzungsband: Nation und Nationalität. Karlsruhe: Braun: 116-151.

Boehm, M. H. (1932) Das eigenständige Volk. Volkstheoretischen Grundlagen der Ethnopolitik und Geisteswissenschaften. Göttingen: Vandenhoeck \& Ruprecht.

Boehm, M. H. (1935) Volkstheorie und Volkstumspolitik der Gegenwart, Berlin: Junker \& Dunnhaupt.

Boehm, M. H. (1938) Volkstumswechsel und Assimilationspolitik. In: Freisler, R./Löning, G. A./Nipperdey, H. C. (Hg.) Festschrift Justus Wilhelm Hedemann zum sechzigsten Geburtstag am 24. April 1938. Jena: Frommannsche Buchhandlung Biedermann: 134-158.

Boehm, M. H. (1959) Die Reorganisation der Deutschtumsarbeit nach dem ersten Weltkrieg. In: Ostdeutsche Wissenschaft. Jahrbuch des Ostdeutschen Kulturrates, Vol. 5: 9-34.

Broszat, M. (1958) Die völkische Ideologie und der Nationalsozialismus. In: Deutsche Rundschau, No. 1: 53-68. 
Brown, D. (2000) Contemporary Nationalism: Civic, Ethnocultural and Multicultural Politics. New York: Routledge.

Bruns, C. G. (1929) Grundlagen und Entwicklung des internationalen Minderheitenrechts. Berlin: Deutsche Gesellschaft für Nationalitätenrecht.

Claude, I. L. (1955) National Minorities. An International Problem. Cambridge: Harvard University Press.

Diner, D. (1989) Rassistisches Völkerrecht. Elemente einer nationalsozialistischen Weltordnung, Vierteljahrshefte für Zeitgeschichte, No. 1: 23-56.

Dodd, W. F. (ed.) (1909) Modern Constitutions: A Collection of the Fundamental Laws of Twenty-two of the Most Important Countries of the World, With Historical and Bibliographical Notes. Chicago: The University of Chicago Press.

Dörge, H. (1931) Der autonome Verband im geltenden Staats- und Völkerrecht. Ein Beitrag zu den Grundlagen des Rechts der nationalen Minderheit. Wien/Leipzig: Braumüller.

Duparc, J. F. (1922) La protection des minorités de race, de langue et de religion. Étude des droit des gens. Paris: Dalloz.

Eisenmann, L. (1926) The Problem of Minorities. New York: Carnegie Endowment for International Peace.

Fraenkel, E. (1991) Deutschland und die westlichen Demokratien. Frankfurt a.M.: Suhrkamp.

Gerber, H. (1926) Kulturautonomie als Eigenart minderheitenrechtlicher Ordnung und ihre Verwirklichung nach der estnischen Verfassung. In: Juristische Fakultät der Universität Marburg (Hg.) Festschrift für Ludwig Traeger zum 70. Geburtstage am 10. Juni 1926. Berlin: Stilke.

Göthel, T. (2002) Demokratie und Volkstum. Die Politik gegenüber den nationalen Minderheiten in der Weimarer Republik. Köln: SH-Verlag.

Grothe, H. (1921) Schicksale und Entwicklung des Auslanddeutschtums seit 1914. In: Verein für das Deutschtum im Ausland (Hg.) Jahrbuch für 1922. Berlin: 25-189.

Gütermann, C. (1979) Das Minderheitenschutzverfahren des Völkerbundes. Berlin: Duncker \& Humblot.

Haar, I. (2000) Historiker im Nationalsozialismus. Deutsche Geschichtswissenschaft und der „Volkstumskampf“ im Osten. Göttingen: Vandenhoeck \& Ruprecht.

Heckel, M. (2001) Deutschland im konfessionellen Zeitalter. Göttingen: Vandenhoeck \& Ruprecht.

Heckel, M. (2007) Der Augsburger Religionsfriede. In: Gaertner, J./Godel, E. (Hg.) Religionsfreiheit und Frieden. Vom Augsburger Religionsfrieden zum europäischen Verfassungsvertrag. Frankfurt: Peter Lang: 13-33.

Hoffmann, L. (1991) Das „Volk“. Zur ideologischen Struktur eines unvermeidbaren Begriffs. In: Zeitschrift für Soziologie, No. 3: 191-208.

Janowsky, O. (1945) Nationalities and National Minorities. New York: Macmillan.

Jellinek, G. (1898) Das Recht der Minoritäten. Wien: Hölder.

Kann, R. A. (1964) Das Nationalitätenproblem der Habsburgermonarchie. Geschichte und Ideengehalt der nationalen Bestrebungen vom Vormärz bis zur Auflösung des Reiches im Jahre 1918, Vol. 1. Graz/Köln: Böhlau.

Kimminich, O. (1980) Regelungen der Minderheiten- und Volksgruppenprobleme in der Vergangenheit. In: Wittmann, F./Bethlen, S. (Hg.) Volksgruppenrecht. Ein Beitrag zur Friedenssicherung. München/Wien: Olzog: 37-52.

Klauss, H. (1937) Nationalsozialistisches Volksgruppenrecht (Diss.). Heidelberg. 
Kloss, H. (1969) Grundfragen der Ethnopolitik im 20. Jahrhundert. Die Sprachgemeinschaften zwischen Recht und Gewalt. Wien: Braumüller.

Klueting, H. (2007) Das Konfessionelle Zeitalter. Europa zwischen Mittelalter und Moderne. Darmstadt: Primus.

Kugelmann, D. (2001) Minderheitenschutz als Menschenrechtsschutz. Die Zuordnung kollektiver und individueller Gehalte des Minderheitenschutzes. In: Archiv des Völkerrechts 39: 233-267.

Lanarès, P. (1964) La liberté religieuse dans les conventions internationales et dans le droit public général (Diss.), Geneva.

Laun, R. (1923) Die Volkszugehörigkeit und die völkerrechtliche Vertretung der nationalen Minderheiten. In: Niemeyers Zeitschrift für Internationales Recht XXXI: 252-282.

Lijphart, A. (1977) Democracy in Plural Societies. A Comparative Approach. New Haven: Yale University Press.

Lijphart, A. (1999) Patterns of Democracy. Government Forms and Performance in Thirty-Six Countries. New Haven: Yale University Press.

Loesch, K. C. v. (1926) Paneuropa - Völker und Staaten. In: Loesch, K. C. v. (Hg.) Staat und Volkstum. Berlin: Deutscher Schutzbund: 7-50.

Loesch, K. C. v. (Hg.) (1925) Volk unter Völkern. Breslau: Hirt.

Macartney, C. A. (1934) National States and National Minorities. London: Oxford University Press.

May, S. (2008) Language and Minority Rights: Ethnicity, Nationalism, and the Politics of Language. New York: Routledge.

Mommsen, H. (1989) Die verspielte Freiheit. Der Weg der Republik von Weimar in den Untergang 1918 bis 1933. Frankfurt/Berlin: Propyläen.

Münz, R./Ohliger, R. (2001) Auslandsdeutsche. In: François, E./Schulze, H. (Hg.) Deutsche Erinnerungsorte, Vol. 1. München: Beck: 370-388.

Neumann, F. L. (1966) Behemoth. The Structure and Practice of National Socialism 1933-1944. New York: Harper \& Row.

Palleit, L. (2008) Völkerrecht und Selbstbestimmung. Zum Begriff des Selbstbestimmungsrechts der Völker der deutschen und österreichischen Völkerrechtswissenschaft 1918 bis 1933. Baden-Baden: Nomos.

Pan, F. (1999) Der Minderheitenschutz im Neuen Europa und seine historische Entwicklung. Wien: Braumüller.

Pearson, R. (1983) National Minorities in Eastern Europe 1848-1945. London: Macmillan.

Pelinka, A. (2009) Überwindung oder Vertiefung von Hegemonie? Politische Kultur „lernen“. In: Salzborn, S. (Hg.) Politische Kultur - Forschungsstand und Forschungsperspektiven. Frankfurt a.M.: Peter Lang: 31-44.

Pinwinkler, A. (2003) „Grenze“ als soziales Konzept: Historisch-demographische Konstrukte des „Eigenen“ und des „Fremden“. In: Comparativ. Leipziger Beiträge zur Universalgeschichte und vergleichenden Gesellschaftsforschung, No. 3: 31-48.

Pircher, E. H. (1979) Der vertragliche Schutz ethnischer, sprachlicher und religiöser Minderheiten im Völkerrecht. Bern: Stampfli.

Prehn, U. (2001) „Volk“ und „Raum“ in zwei Nachkriegszeiten. Kontinuitäten und Wandlungen in der Arbeit des Volkstumsforschers Max Hildebert Boehm. In: Knoch, H. (Hg..) Das Erbe der Provinz. Heimatkultur und Geschichtspolitik nach 1945. Göttingen: Wallstein: 50-72.

Pritchard, S. (2001) Der völkerrechtliche Minderheitenschutz. Historische und neuere Entwicklungen. Berlin: Duncker \& Humblot. 
Raschhofer, H. (1931) Hauptprobleme des Nationalitätenrechts. Stuttgart: Enke.

Raschhofer, H. (1964) Zur Entstehung des Volksgruppenrechts. In: Niedersächsisches Ministerium für Vertriebene, Flüchtlinge und Kriegsgeschädigte (Hg.) Heimatrecht in polnischer und in deutscher Sicht. Leer/Ostfriesland: Rautenberg: 82-90.

Raschhofer, H. (1980) Das altösterreichische Nationalitätenrecht und die deutschen Volksgruppen nach 1918. In: Wittmann, F./Bethlen, S. (Hg.) Volksgruppenrecht. Ein Beitrag zur Friedenssicherung. München/Wien: Olzog: 53-69.

Reydellet, R. (1937) La protection des minorités. Etat du problème - Ses possibilités d'évolution. Paris: Librairie Technique et Economique.

Salzborn, S. (2005a) Ethnisierung der Politik. Theorie und Geschichte des Volksgruppenrechts in Europa. Frankfurt/New York: Campus.

Salzborn, S. (2005b) Europe des régions et idéologie ethnique: La notion de groupe ethnique. In: Géopolitique. Revue d'Institut International de Géopolitique, No. 89: 8186.

Scheuermann, M. (2000) Minderheitenschutz contra Konfliktverhütung? Die Minderheitenpolitik des Völkerbundes in den zwanziger Jahren. Marburg: Herder-Institut.

Schmid, C. L. (2001) The Politics of Language: Conflict, Identity and Cultural Pluralism in Comparative Perspective. Oxford: Oxford University Press.

Schwarz, G. (1996) Die nationalsozialistischen Lager. Frankfurt: Fischer.

Sontheimer, K. (1994) Antidemokratisches Denken in der Weimarer Republik. Die politischen Ideen des deutschen Nationalismus zwischen 1918 und 1933. München: Deutscher Taschenbuchverlag.

Stourzh, G. (1999) Ethnisierung der Politik in Altösterreich. In: Wiener Journal, No. 228: $35-40$.

Veiter, T. (1938) Nationale Autonomie. Rechtstheorie und Verwirklichung im positiven Recht. Wien/Leipzig: Braumüller.

Veiter, T. (1968) Völkerrechtsnormen und Völkerrechtsgrundsätze zum Schutz nationaler Minderheiten. In: Österreichische Juristen-Zeitung, No. 9: 225-234.

Veiter, T. (1970) Volksgruppenrecht und ewige Rechtsgrundsätze (undated, ca. 1970). Vorarlberger Landesbibliothek Bregenz, Estate of Theodor Veiter, sig. AS 10.

Veiter, T. (1984) Nationalitätenkonflikt und Volksgruppenrecht im ausgehenden 20. Jahrhundert. Die Entwicklung des ethnischen Konflikts - Rechtsprobleme im ausgehenden zwanzigsten Jahrhundert - Schlußfolgerungen, Vol. 1. München: Bayerische Landeszentrale für politische Bildungsarbeit.

Walk, J. (Hg.) (1996) Das Sonderrecht für die Juden im NS-Staat. Eine Sammlung der gesetzlichen Maßnahmen und Richtlinien - Inhalt und Bedeutung. Heidelberg: Müller.

Walz, G. A. (1939) Neue Grundlagen des Volksgruppenrechts. In: Zeitschrift für Völkerrecht XXIII: 129-164.

Ziegert, G. (1937) Das autonome deutsche Volksgruppenrecht (Diss.). Breslau.

Samuel Salzborn is a substitute professor of political science with a focus on democracy studies at the Institute for Political Science at the University of Giessen. Main research interests: Political Theory and the History of Ideas, Political Culture Studies, Methods of Political Science.

E-Mail: samuel.salzborn@sowi.uni-giessen.de 